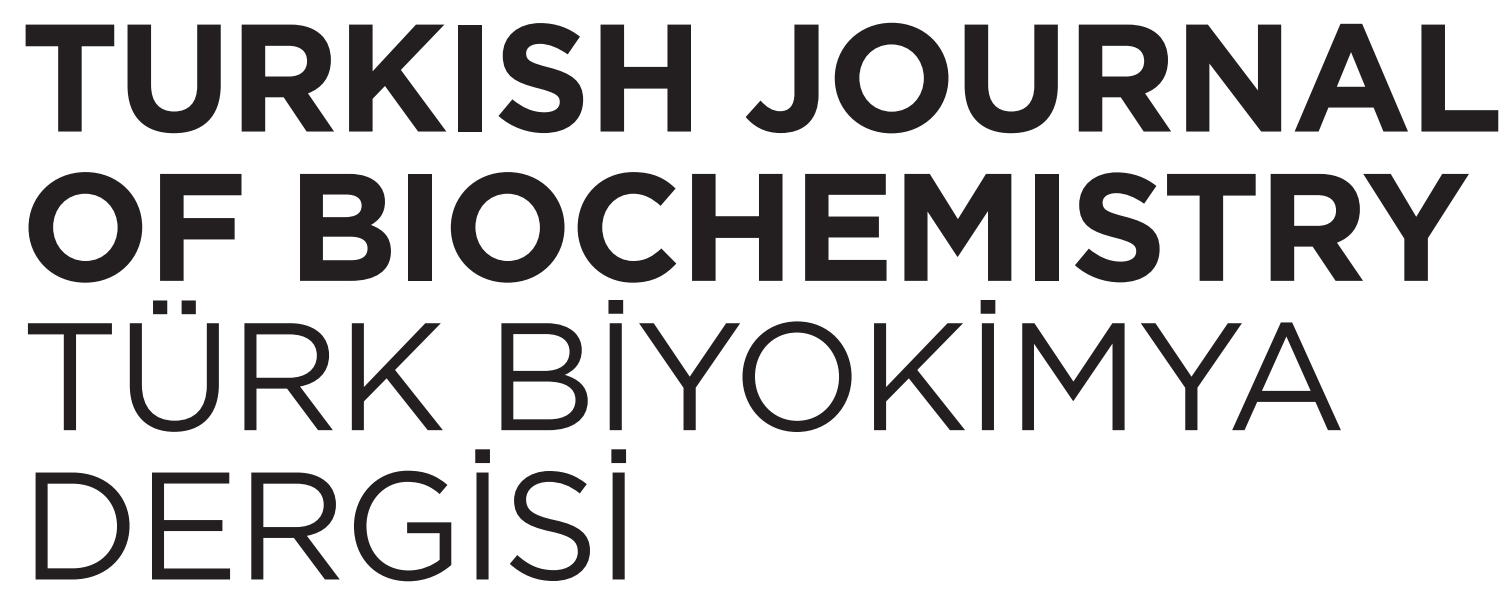

\title{
OFFICIAL JOURNAL OF THE TURKISH BIOCHEMICAL SOCIETY
}

EDITOR IN CHIEF [BAŞ EDITÖR]

Doğan Yücel, Ankara, TR

\section{VICE EDITORS}

\section{[YARDIMCI EDITÖRLER]}

Aylin Sepici Dinçel, Ankara, TR

Merve Sibel Güngören, Ankara, TR

Oytun Portakal, Ankara, TR

Muhittin Serdar, Ankara, TR

Mehmet Şeneş, Ankara, TR

\section{ASSOCIATE EDITORS [BÖLÜM EDITÖRLERI]}

Sedat Abuşoğlu, Konya, TR Ebubekir Bakan, Erzurum, TR Sreeparna Banerjee, Ankara, TR Emine Bayraktar, Ankara, TR Ebru Bodur, Ankara, TR Murat Bolayırl, İstanbul, TR Abdurrahman Coşkun, İstanbul, TR Özlem Dalmızrak, Nicosia, TRNC Birsen Can Demirdöğen, Ankara, TR
Suat Erdoğan, Edirne, TR Uzay Görmüş, Solna, SE Levent Kayrın, Kyrenia, TRNC Semra Koçtürk, İzmir, TR Işıl Aksun Kurnaz, Kocaeli, TR Melek Özkan, Kocaeli, TR Yeşim Özkan, Ankara, TR Ebru Saatçi, Kayseri, TR Çağdaş Son, Ankara, TR Alaattin Şen, Denizli, TR Ajlan Tükün, Ankara,TR Hamdi Uysal, Ankara, TR Serenay Elgün Ülkar, Ankara, TR Süha Yalçın, İstanbul, TR İlhan Yaylım, İstanbul, TR Fatma Meriç Yılmaz, Ankara, TR Meral Yüksel, Istanbul, TR

\author{
STATISTICS EDITORS \\ [ISTATISTIK EDITÖRLERi] \\ Erdal Coşgun, Redmond, WA, USA \\ Sevilay Karahan, Ankara, TR \\ Jale Karakaya, Ankara, TR

\section{TECHNICAL EDITORS} \\ (TEKNIK EDITÖRLER) \\ Tülin Bayrak, Ordu, TR \\ Birsen Can Demirdöğen, Ankara, TR \\ Merve Sibel Güngören, Ankara, TR \\ Elvan Laleli Şahin, Dallas, USA \\ Duygu Şahin, Istanbul, TR \\ Z. Onur Uygun, İzmir, TR \\ Oğuzhan Zengi, İstanbul, TR
}

CORRESPONDENCE [YAZI IȘLERI]

Nermin Şahan, Ankara, TR 


\section{EDITORIAL BOARD [EDITÖORLER KURULU]}

Erdal Karaöz, Department of Histology and Embryology, Faculty of Medicine, İstinye University, İstanbul, TURKEY

Reşat Apak, Department of Chemistry, Faculty of Engineering, İstanbul University Cerrahpaşa Research Information System, İstanbul, TURKEY

Khosrow Adeli, Molecular Medicine, Research Institute, The Hospital for Sick Children, University of Toronto, Toronto, Ontario, CANADA Diler Aslan, Department of Biochemistry, Faculty of Medicine, Pamukkale University, Denizli, TURKEY

Cumhur Bilgi, Department of Medical Biochemistry, University of Yüksek İhtisas, Ankara, TURKEY

Anyla Bulo-Kasneci, Laboratory Department, University Hospital Center "Mother Teresa", Tirana, ALBANIA

Orhan Değer, Department of Medical Biochemistry, Faculty of Medicine, Karadeniz Technical University, Trabzon, TURKEY Elif Demirkan, Department of Biology, Faculty of Arts \& Sciences, Uludağ University, Bursa, TURKEY

Z. Günnur Dikmen, Department of Biochemistry, Faculty of Medicine, Hacettepe University, Ankara, TURKEY

Miral Dizdaroğlu, National Institute of Standards and Technology, Gaithersburg, MD, USA

Mustafa B. A. Djamgoz, Department of Life Sciences, Faculty of Natural Sciences, Imperial College, London, UNITED KINGDOM Figen Erkoç, Department of Biology Education, Faculty of Gazi Education, Gazi University, Emeritus, Ankara TURKEY Gökhan Hotamişlıgil, Department of Genetics and Complex Diseases, Harvard School of Public Healt, Boston, USA

Mehmet Kesimer, Department of Pathology and Laboratory Medicine, Marsico Lung Institute, University of North Carolina at Chapel Hill, NC, USA

İran Küfrevioğlu, Department of Chemistry, Faculty of Art \& Sciences, Atatürk University, Erzurum, TURKEY

Nada Majkic-Singh, Institute of Medical Biochemistry, Pharmaceutical Faculty and Clinical Centre of Serbia, Belgrade, SERBIA

Gülgün Oktay, Department of Medical Biochemistry, Faculty of Medicine, University of Dokuz Eylül, İzmir, TURKEY
İ. Hamdi Öğüss, Department of Medical Biochemistry, Faculty of Medicine, Near East University, Nicosia, Emeritus, TRNC Yeşim Özarda, Department of Medical Biochemistry, Faculty of Medicine, Uludağ University, Bursa, TURKEY

Tomris Özben, Department of Medical Biochemistry, Faculty of Medicine, Akdeniz University, Antalya, TURKEY

Nazmi Özer, Faculty of Pharmacy, Girne American University, Nicosia TRNC

Israel Pecht, Department of Immunology, Weizmann Institute of Science, Rehovot, ISRAEL

Mario Plebani, Department of Medical Sciences, University of Padova, Padova, ITALY

Demetrios Rizos, Hormonal and Biochemical Laboratory, Aretaieio Hospital, University of Athens, Athens, GREECE

George Russev, Bulgarian Academy of Sciences, Institute of Molecular Biology, Sofia, BULGARIA

Fahri Saatçioğlu, Department of Biosciences, University of Oslo, Oslo, NORWAY

Ferhan Girgin Sağın, Department of Medical Biochemistry, Faculty of Medicine, Ege University, İzmir, TURKEY

Aziz Sancar, Department of Biochemistry and Biophysics, University of North Carolina School of Medicine, Chapel Hill, NC, USA

Praveen Sharma, All India Institute of Medical Sciences, Jodhpur, INDIA

Emin Sofic, Department of Chemistry, Faculty of Science, Sarajevo University, Sarajevo, BOSNIA AND HERZEGOVIA

Eser Sözmen, Department of Medical Biochemistry, Faculty of Medicine, University of Ege, İzmir, TURKEY

Abdullah Tuli, Department of Medical Biochemistry, Faculty of Medicine, Cukurova University, Adana, TURKEY

Ali Ünlü, Department of Biochemistry, Faculty of Medicine, Selçuk University, Konya, TURKEY

Sedef Yenice, Department of Clinical Chemistry, Group Florence Nightingale Hospitals, İstanbul, TURKEY

Turkish Journal of Biochemistry (TJB), official journal of Turkish Biochemical Society, is issued electronically every 2 months. Research articles, reviews, short communications, technical reports, case presentations, opinions, and letters to the editor, that have not published elsewhere, on biochemistry, clinical biochemistry, molecular biology, molecular genetics, biotechnology, bioinformatics, bioengineering, and their educational disciplines are published in the journal.

The main aim of the journal is to support the research and publishing culture by ensuring that every published manuscript has an added value and thus providing international acceptance of the "readability" of the manuscripts published in the journal.

e-ISSN 1303-829X

All information regarding notes for contributors, subscriptions, Open access, back volumes and orders is available online at www.degruyter.com/view/j/tjb.

RESPONSIBLE EDITOR Doğan Yücel PhD, Assoc Professor of Biochemistry, Department of Medical Biochemistry, Ankara Training and Research Hospital, University of Health Sciences, 06340, Ankara, Turkey, Tel: +90312 595 321, Email: doyucel@yahoo.com

JOURNAL MANAGER Alexander Görlt, De Gruyter, Genthiner Straße 13, 10785 Berlin, Germany. Tel.: +49 (0) $3026005-234$, Fax: +49 (0) 30260 05-250, Email: alexander.goerlt@ degruyter.com

RESPONSIBLE FOR ADVERTISEMENTS Markus Kügel, De Gruyter, Rosenheimer Str. 143, 81671 München, Germany, Tel.: +49 $8976902-424$, e-mail: anzeigen@degruyter.com

TYPESETTING TNQ Technologies, Chennai, India 